\title{
The effect of the source of nitrogen on protein fractions and their proportions in barley grains
}

\author{
ULLA LALLUKKA, EERO VARIS and RITVA REPO \\ Department of Plant Husbandry, \\ University of Helsinki, 00710 Helsinki 71
}

\begin{abstract}
The effects of fertilizer nitrogen, preceeding leguminous crop in rotation, and mixed cropping of barley with field beans on the protein fractions in mature barley grains were studied with the material collected from three experiment sites in southern Finland. With an increase in nitrogen application, the total $\mathrm{N}$ in grains as well as nitrogen in the different Osborne fractions increased. The relative amounts of protein fractions changed: prolamin increased, glutelin remained fairly constant, and salt-soluble fraction decreased. The preceeding leguminous crops, pea and field bean, increased the nitrogen content in barley as well as the proportion of prolamin $\mathrm{N}$. The share of prolamin $\mathrm{N}$ in barley following leguminous plants was higher than in barley following oats, where the similar total $\mathrm{N}$ content was due to fertilizer nitrogen. In mixed cropping of barley and field beans prolamin $\mathrm{N}$ in harvested barley grains also increased with the increased total nitrogen due to an increase either in fertilizer application or in the share of field bean in the mixture. In this case there was no clear difference in the proportions of prolamin $\mathrm{N}$ between the treatments.

The proportions of salt-soluble fractions were slightly higher and that of storage protein lower in Finnish barleys studied than in the results from other studies, where Central European cultivars with larger grains were used.
\end{abstract}

\section{Introduction}

With the rising prices for energy and fertilizers, biological nitrogen fixation has become a goal for intensive studies in many countries. In Finland as well, several research projects are conducted ${ }^{1)}$ including e.g. the utilization of biologically fixed nitrogen for cereals either by growing leguminous plants preceeding the cereal crop or mixed with it.

Nitrogen $\left(\mathrm{N}_{2}\right)$ fixed by leguminous plants and thus available to the following cereals, is in organic form and is therefore mobilized more slowly than $\mathrm{N}$ from fertilizers. The effects of a late application of fertilizer $\mathrm{N}$ on the grain yield and its protein content and quality has been much studied (SELKE

\footnotetext{
1) The projects are primarily financed by The Academy of Finland and by SITRA, the Finnish National Fund for Research and Development.
} 
1940, MICHAEL 1963, ZOSCHKE 1973). It is known that a late application of fertilizer $\mathrm{N}$ increases the protein content of the grain, which improves the baking characteristics of grains for flour but not the feeding quality of cereals for fodder, except for oats. Very little is known about the effects of biologically fixed $\mathrm{N}$ on the quality of protein in cereals. In present study, the protein quality in barley grown succeeding or mixed with leguminous plants was investigated using OSBORNE's fractioning.

\section{Material and methods}

The material analysed consisted of three experiment series. In two series the effects of $\mathrm{N}$ application and effects of the preceeding crop in rotation on barley protein were studied. In the third series the effects of mixed cropping of barley and field bean (Vicia faba L.) on barley protein were studied. In brief, the experiments were as follows:

Trial series 1:

Factors: - $\mathrm{N}$ application (40 and $80 \mathrm{~kg} / \mathrm{ha}$ )

- Preceeding crop in rotation (oats, pea, field bean, pea-oats pea dominating, pea-oats dominating) (split-plot design)

Trial series 2:

Factors: - $\mathrm{N}$ application (40 and $80 \mathrm{~kg} / \mathrm{ha}$ )

- $\mathrm{N}$ application on preceeding crop in rotation (12, 50 and $88 \mathrm{~kg} /$ ha)

Trial series 3:

- Preceeding crop (oats, pea and field bean) (split-split-plot)

Factors: - $\mathrm{N}$ application (40 and $80 \mathrm{~kg} / \mathrm{ha}$ )

- Barley-field bean mixtures (split-plot)

The trials were carried out at three places in southern Finland: on the Viikki Experimental Farm of the University of Helsinki, on the Experimental Farm of Hankkija at Hyrylä, and on Satakunta Experimental Station of the Agricultural Research Centre at Peipohja. All the farms are situated between $60^{\circ} \mathrm{N}$ and $61^{\circ} \mathrm{N}$. The yields of trials in each series were used for analyses ${ }^{1)}$. The barley cultivar used in series 1 and 2 was Hankkija 673. In series 3 cultivars Hankkijan Pokko and Hankkijan Aapo were used.

Protein was fractioned using the method developed by KøIE and NIELSEN (1977). Lipids were, however, not removed because they did not change the amount of extracted proteins. Extracted with this method, prolamin contains all the protein with low lysine content $(<2 \%)$ (MIFLIN and SHEWRY 1979). $\mathrm{N}$ in protein fractions was determined with KJELDAHL techique. In this study, most attention was paid to prolamin $\mathrm{N}$ considering that variation observed in its content would well reflect protein quality of the grain. $\mathrm{N}$ in the other fractions was determined as well, but nonprotein $\mathrm{N}$, and

\footnotetext{
1) The results for grain and protein yields obtained will be given in a later paper. Here, only the results on protein fractioning are given.
} 


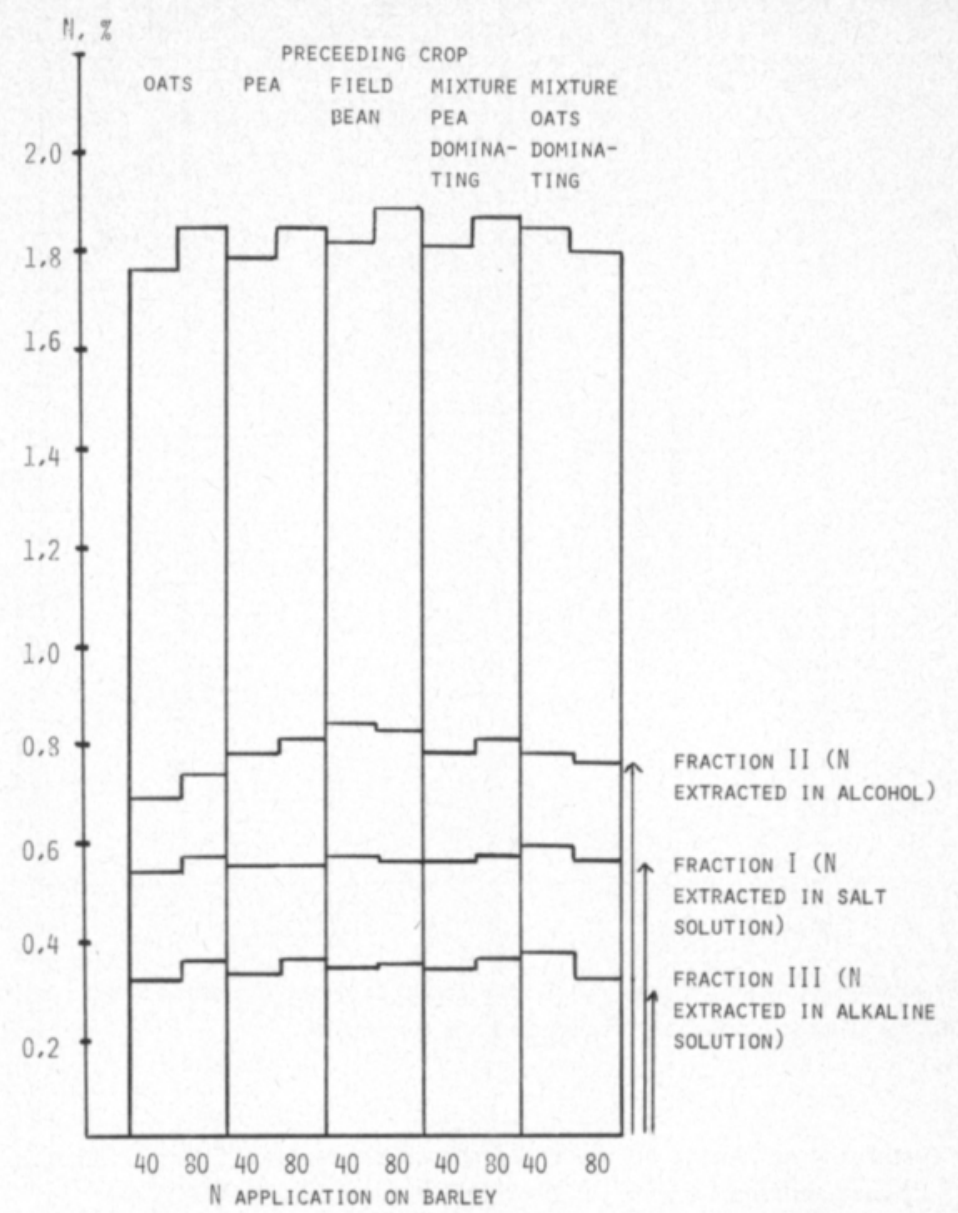

Fig. 1. Effects of the rate of nitrogen application and the preceeding crop in rotation on the amount and quality of protein in barley. Nitrogen percentages of the fractions indicate proportion of nitrogen in the DM of the whole sample. Thus the sum of the percentages $\sim$ total nitrogen percentage.

water- and salt-soluble $\mathrm{N}$ (albumins and globulins) were not separated. They were all included in fraction I. Fraction II contains prolamin and fraction III glutelin. $\mathrm{N}$ extracted in these three fractions corresponded from 90 to 100 per cent of the total $\mathrm{N}$. The proportion of residue not separately determined remained in most cases below 5 percent.

\section{Results and discussion}

The results of protein fractioning of barley grains are presented in Figures 1 to 3 and Tables 1 to 3 . $N$ application to barley at sowing increased prolamin $\mathrm{N}$ in almost all the treatments, in which total $\mathrm{N}$ increased. Partly due the small material, the changes were not always statistical significant. Glutelin $\mathrm{N}$ seemed to rise with increasing rate of nitrogen application, but as well absolutely and relatively less than the prolamin N. Relatively, the proportions of nitrogen in fractions changed as follows (Tables 4 and 6): prolamin $\mathrm{N}$ 


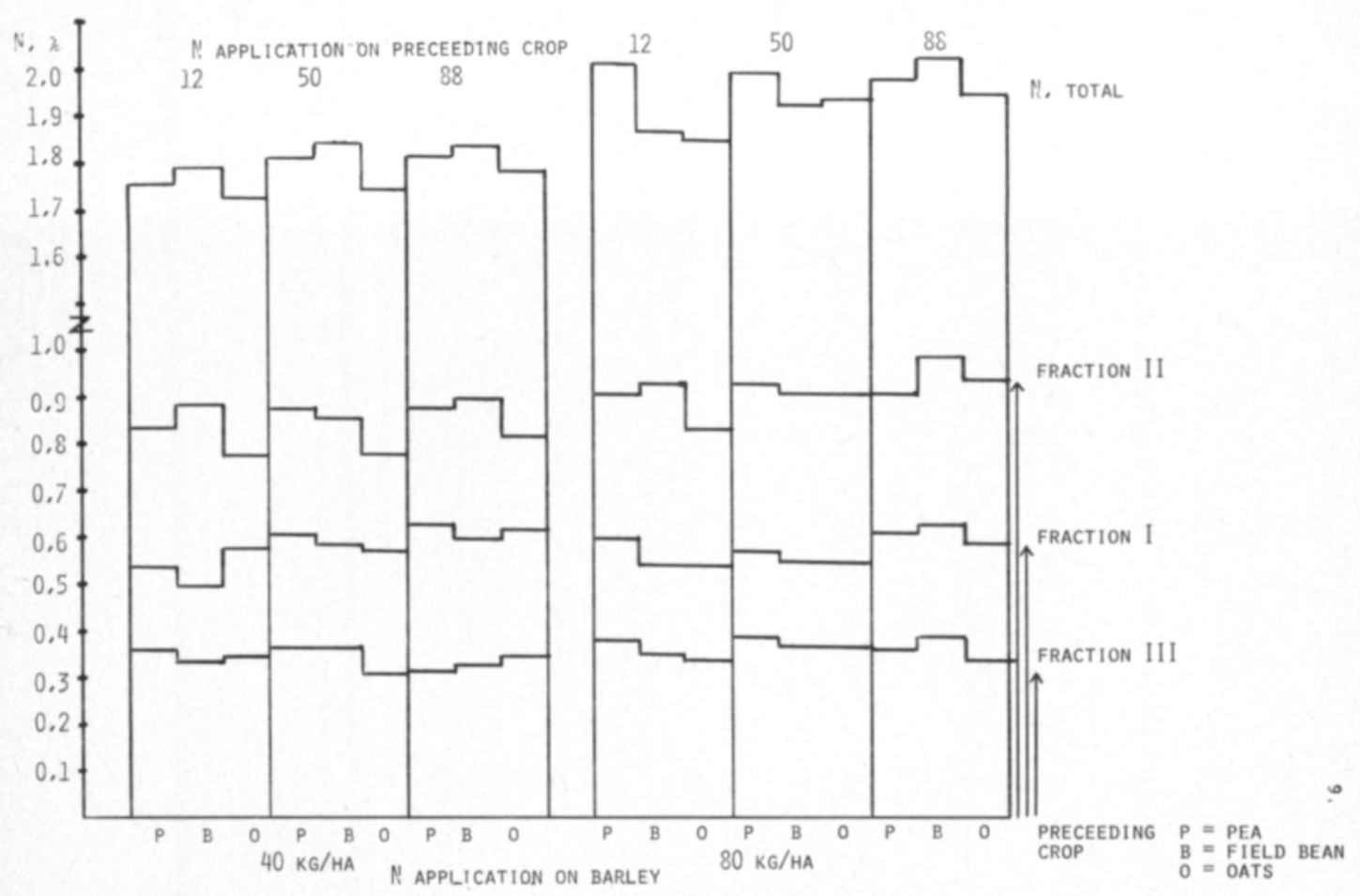

Fig. 2. Effects of nitrogen application to the preceeding crop and of the preceeding crop itself on protein quality in barley dressed with different nitrogen doses.

Table 1. Analysis of variance on the effects of nitrogen application and the preceeding crop on the total $\mathrm{N}$ in barley and on $\mathrm{N}$ contents in the different protein fractions (Fig. 1).

\begin{tabular}{|c|c|c|}
\hline & $\begin{array}{l}\text { Albumin + Globuli } \\
+ \text { nonprotein } \mathrm{N}, \%\end{array}$ & $\begin{array}{l}\text { Prolami } \\
\mathrm{N}, \%\end{array}$ \\
\hline
\end{tabular}

$\mathrm{N}$ appli-

cation $=\mathrm{A}$

Preceeding

crop $=$ B

$A \times B$

Significance of

differences

$$
\begin{array}{rrr}
-=P>0.1 & 0=P<0.1 \\
\mathbf{x}=\mathrm{P}<0.05 & \mathbf{x x}=\mathrm{P}<0.01
\end{array}
$$

increased markedly, salt-soluble $\mathrm{N}$ decreased, and glutelin $\mathrm{N}$ remained about the same in all levels of nitrogen application. A corresponding regularity in the changes of protein fractions with the increasing protein content in grain was already observed by BISHOP (1928), and several others after him.

In the trials concerning the effect of the preceeding leguminous crop in rotation on protein quantity was also statistically significant. By increasing the nitrogen content of the following barley in rotation, pea and field bean markedly affected the quantity of prolamin N (fraction II) in barley. Also the 


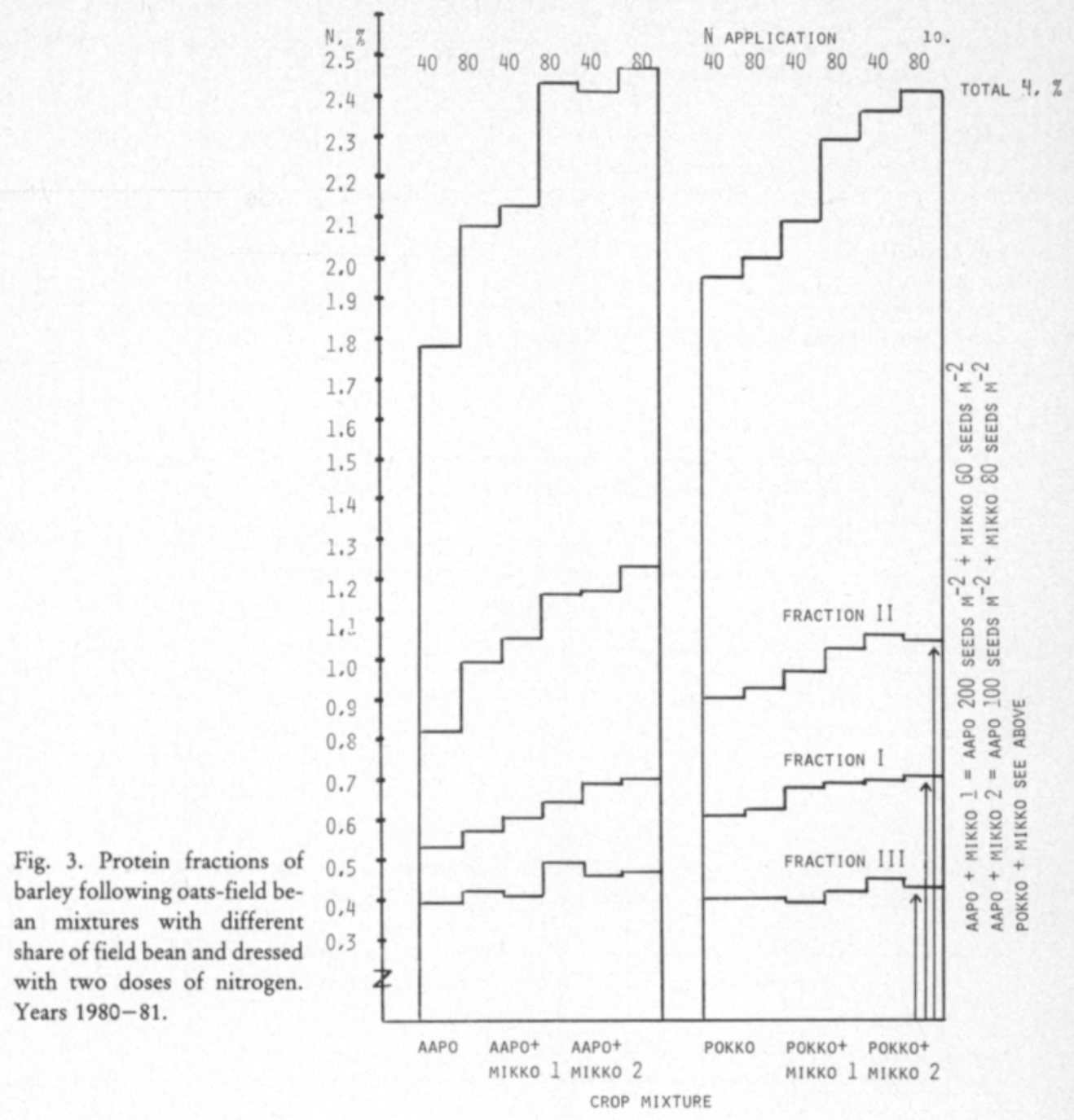

Table 2. Analysis of variance on the effects of nitrogen application, of nitrogen application on the preceeding crop, and of the preceeding crop itself on the total $\mathrm{N}$ in barley and on $\mathrm{N}$ contents in the different protein fractions (Fig. 2).

\begin{tabular}{lcccc} 
Factor & $\begin{array}{c}\text { Albumin + Globulin } \\
+ \text { nonprotein N, \% }\end{array}$ & $\begin{array}{c}\text { Prolamin } \\
\mathrm{N}, \%\end{array}$ & $\begin{array}{c}\text { Glutelin } \\
\mathrm{N}, \%\end{array}$ & $\begin{array}{c}\text { Total } \\
\mathrm{N}, \%\end{array}$ \\
\hline $\begin{array}{l}\mathrm{N} \\
\text { during sowing = A }\end{array}$ & - & - & - & 0 \\
$\mathrm{~N}$ application during \\
preceeding year = B
\end{tabular}

Significance of differences, see footnote in Table 1. 
Table 3. Analysis of variance on the effects of nitrogen application and crop mixture on $\mathrm{N}$ content in barley and on $\mathrm{N}$ contents in the different protein fractions (Fig. 3).

\begin{tabular}{lcccc} 
Factor & $\begin{array}{c}\text { Albumin +Globulin } \\
+ \text { nonprotein N, \% }\end{array}$ & $\begin{array}{c}\text { Prolamin } \\
\mathrm{N}, \%\end{array}$ & $\begin{array}{c}\text { Glutelin } \\
\mathrm{N}, \%\end{array}$ & $\begin{array}{c}\text { Total } \\
\mathrm{N}, \%\end{array}$ \\
\hline $\mathrm{N}$ application $=\mathrm{A}$ & - & - & - & 0 \\
Crop mixture $=\mathrm{B}$ & $\mathrm{xx}$ & $\mathrm{xx}$ & - & $\mathbf{x x}$ \\
$\mathrm{A} \times \mathrm{B}$ & - & - & - & - \\
\hline
\end{tabular}

Significance of differences, see footnote in Table 1.

Table 4. Effect of nitrogen application on $\mathrm{N}$ content in barley and on the relative proportions of $\mathrm{N}$ in different protein fractions in experiments presented in Figure 1.

\begin{tabular}{lcccc}
\hline & \multicolumn{2}{c}{ Relative proportion of $\mathrm{N}$ in fractions of the extracted } \\
nitrogen & Total \\
$\mathrm{N}$ application & Fraction I, \% & Fraction II, \% & Fraction III, \% & N, \% \\
\hline $\mathrm{N}, 40 \mathrm{~kg} / \mathrm{ha}$ & 33.5 & 46.1 & 20.3 & 1.80 \\
$\mathrm{~N}, 80 \mathrm{~kg} / \mathrm{ha}$ & 33.1 & 46.4 & 20.4 & 1.85 \\
\hline
\end{tabular}

Table 5. Effect of the preceeding crop on $\mathrm{N}$ content in barley and on the relative proportions of $\mathrm{N}$ in the different protein fractions in experiments presented in Figure 1.

\begin{tabular}{|c|c|c|c|c|}
\hline \multirow[b]{2}{*}{ Preceeding crop } & \multicolumn{3}{|c|}{$\begin{array}{l}\text { Relative proportion of } \mathrm{N} \text { in fractions of the extracted } \\
\text { nitrogen }\end{array}$} & \multirow{2}{*}{$\begin{array}{l}\text { Total } \\
\text { N, \% }\end{array}$} \\
\hline & Fraction I, \% & Fraction II, \% & Fraction III, \% & \\
\hline Oats & 34.2 & 44.5 & 20.8 & 1.81 \\
\hline Pea & 32.6 & 46.8 & 20.3 & 1.82 \\
\hline Field bean & 32.4 & 47.9 & 19.8 & 1.86 \\
\hline $\begin{array}{l}\text { Mixed pea-oats, } \\
\text { pea dominating }\end{array}$ & 33.0 & 46.9 & 20.2 & 1.84 \\
\hline $\begin{array}{l}\text { Mixed pea-oats, } \\
\text { oats dominating }\end{array}$ & 34.0 & 45.5 & 20.5 & 1.82 \\
\hline
\end{tabular}

Table 6. Effect of nitrogen application on the relative proportions of $\mathrm{N}$ in the different protein fractions in barley in experiments presented in Figure 2.

\begin{tabular}{|c|c|c|c|c|}
\hline \multirow[b]{2}{*}{$\mathrm{N}$ application } & \multicolumn{3}{|c|}{$\begin{array}{l}\text { Relative proportion of } \mathrm{N} \text { in fractions of the extracted } \\
\text { nitrogen }\end{array}$} & \multirow{2}{*}{$\begin{array}{l}\text { Total } \\
\text { N, \% }\end{array}$} \\
\hline & Fraction I, \% & Fraction II, \% & Fraction III, \% & \\
\hline $\mathrm{N}, 40 \mathrm{~kg} / \mathrm{ha}$ & 32.8 & 47.7 & 19.4 & 1.79 \\
\hline $\mathrm{N}, 80 \mathrm{~kg} / \mathrm{ha}$ & 30.9 & 49.4 & 19.6 & 1.95 \\
\hline
\end{tabular}


Table 7. Effect of nitrogen application of the preceeding crop on the relative proportions of $\mathrm{N}$ in the different protein fractions in barley in experiments presented in Figure 2.

\begin{tabular}{|c|c|c|c|c|}
\hline \multirow[b]{2}{*}{$\mathrm{N}$ application } & \multicolumn{3}{|c|}{$\begin{array}{l}\text { Relative proportion of } \mathrm{N} \text { in fractions of the extracted } \\
\text { nitrogen }\end{array}$} & \multirow{2}{*}{$\begin{array}{l}\text { Total } \\
\text { N, \% }\end{array}$} \\
\hline & Fraction I, \% & Fraction II, \% & Fraction III, \% & \\
\hline $\mathrm{N}, 12 \mathrm{~kg} / \mathrm{ha}$ & 31.1 & 48.8 & 20.1 & 1.82 \\
\hline $\mathrm{N}, 50 \mathrm{~kg} / \mathrm{ha}$ & 31.8 & 48.4 & 19.8 & 1.87 \\
\hline $\mathrm{N}, 88 \mathrm{~kg} / \mathrm{ha}$ & 32.8 & 48.5 & 18.7 & 1.91 \\
\hline
\end{tabular}

Table 8. Effect of the preceeding crop on the relative proportions of $\mathrm{N}$ in the different protein fractions in barley in experiments presented in Figure 2.

\begin{tabular}{lcccc}
\hline & \multicolumn{2}{c}{ Relative proportion of $\begin{array}{c}\mathrm{N} \text { in fractions of the extracted } \\
\text { nitrogen }\end{array}$} & Total \\
Preceeding crop & Fraction I, \% & Fraction II, \% & Fraction III, \% & N, \% \\
\hline Pea & 32.2 & 48.2 & 19.5 & 1.91 \\
Field bean & 30.7 & 49.7 & 19.5 & 1.88 \\
Oats & 32.7 & 47.7 & 19.6 & 1.82 \\
\hline
\end{tabular}

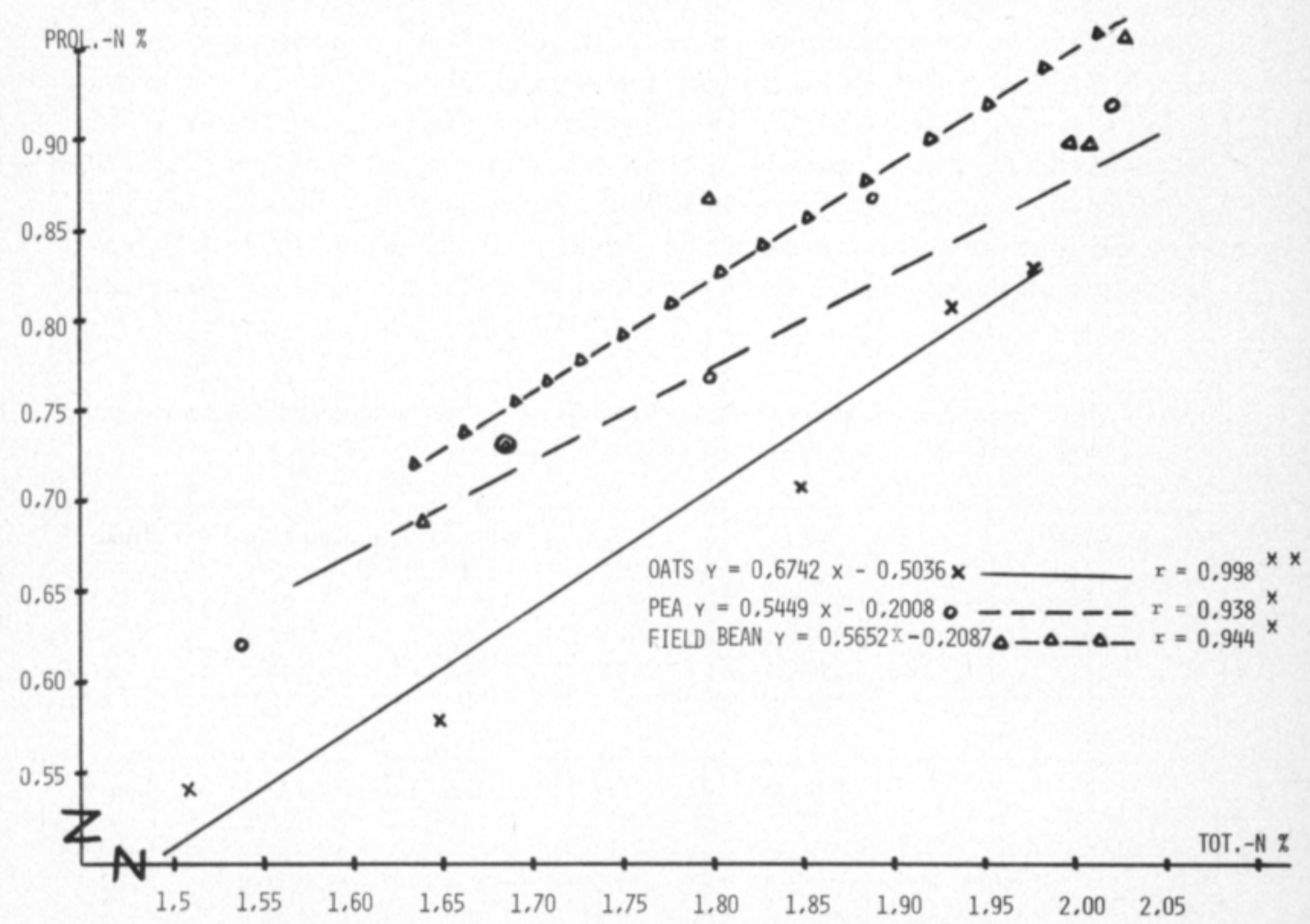

Fig. 4. The regression lines between total $\mathrm{N}$ and prolamin $\mathrm{N}$ in barley grains grown after oats, pea and field bean. 
relative proportion of prolamin $\mathrm{N}$ increased and the proportion of nitrogen in fraction I decreased (Tables 5 and 8). The relative proportion of glutelin $\mathrm{N}$ (fraction III) in barley following pea and field bean seemed to remain slightly lower than in barley following oats.

When single treatments were investigated separately (Figure 2, columns a and $\mathrm{b}$ ) the results indicated that $\mathrm{N}$ fixed by leguminous plants and available to barley during the following year increased the prolamin fraction more than did the fertilizer N. In trial series 1 it was observed that in barley grains with equal $\mathrm{N}$ content, the content of prolamin $\mathrm{N}$ was higher in barley following leguminous plants than oats (Figure 4). Similar results have been reported by BYERS et al. (1978). Biologically fixed nitrogen is apparently more slowly available to the succeeding crop than nitrogen in fertilizers, thus at a late stage of growth barley turns the nitrogen almost solely to prolamin requiring little energy (MITRA et al. 1979). Correspondingly it is the quantity of prolamin $\mathrm{N}$ which has been observed to increase when fertilizer nitrogen has been applied at a late stage of growth, and with marked ${ }^{15} \mathrm{~N}$ it has been possible to show that in the mature grain nitrogen applied late can be found primarily in prolamin and glutelin (MICHAEL et al., 1960).

Nitrogen from fertilizers, which had remained in soil from the previous growing season, increased slightly the total nitrogen as well as the prolamin $\mathrm{N}$ contents (Figure 2), but did not affect the relative proportion of prolamin $\mathrm{N}$ (Table 7). Differences were small and significant only for total N. In the trials where barley was grown in pure stand or mixed with field bean and where different $\mathrm{N}$ applications were used, the relative proportion of prola$\min \mathrm{N}$ increased with the increasing nitrogen content of the grain. This was either due to the increased $\mathrm{N}$ application or the increased proportion of field beans in the mixture (Figure 3). In these trial series it was not clear (Table 9), whether the proportion of prolamin $\mathrm{N}$ increased similarly in both cases. This may be true as the nitrogen taken up by cereals likely originated from fertilizers only. As leguminous plants fix part of the nitrogen they use from

Table 9. Effect of nitrogen application on the relative proportions of $\mathrm{N}$ in the different protein fractions of the barley cultivars, and on total $\mathrm{N}$ in the barley-field bean mixture ${ }^{11}$.

\begin{tabular}{|c|c|c|c|c|c|c|c|c|}
\hline \multirow{2}{*}{$\begin{array}{l}\mathrm{N} \text { application } \\
\mathrm{kg} / \mathrm{ha}\end{array}$} & \multicolumn{3}{|c|}{ Aapo } & \multirow{2}{*}{$\begin{array}{l}\text { Total } \\
\text { N, \% }\end{array}$} & \multicolumn{3}{|c|}{ Mixtures, Aapo and bean } & \multirow{2}{*}{$\begin{array}{l}\text { Total } \\
\text { N, \% }\end{array}$} \\
\hline & I & II & III & & I & II & III & \\
\hline 40 & 30.7 & 47.0 & 22.2 & 1.78 & 29.4 & 50.7 & 19.9 & 2.27 \\
\hline 80 & 28.8 & 49.8 & 21.3 & 2.08 & 28.5 & 51.2 & 20.4 & 2.45 \\
\hline
\end{tabular}

\begin{tabular}{ccccccccc}
\hline & & Pokko & & \multicolumn{3}{c}{ Total } & \multicolumn{3}{c}{ Mixtures, Pokko and bean } & \multicolumn{2}{c}{ Total } \\
& I & II & III & N, \% & I & II & III & N, \% \\
\hline 40 & 31.9 & 47.0 & 21.1 & 1.95 & 32.4 & 47.9 & 19.8 & 2.22 \\
80 & 31.9 & 47.7 & 20.3 & 2.00 & 32.4 & 48.1 & 19.5 & 2.35 \\
\hline
\end{tabular}

1) The relative proportions of different fractions are given as percentages of the extracted nitrogen. 
the atmosphere, more abundant amount of $\mathrm{N}$ remains available to the cereal even in a low level of $\mathrm{N}$ applied.

In the present study the proportions of different fractions in barley slightly deviated from results given elsewhere (IVANKO 1971, EWART 1968). Here the proportion of salt-extracted fraction I was slightly higher, and the proportion of storage proteins II and III correspondingly lower than in barley analysed by IVANKO with respective methods. The results obtained here can, however, be explained with the small grain size of the 6-rowed cultivars Hankkija 673 and Pokko. Therefore, the proportion of protein fraction I occurring mainly in the aleuron and testa can be higher than observed in foreign cultivars with larger grains. The slightly higher portion of storage $\mathrm{N}$ and lower portion of metabolic $\mathrm{N}$ in the third cultivar studied, the two-rowed Aapo, supports the assumption.

\section{Acknowledgements}

The present study was made possible by a grant allowed for us from the Fund of Raisa and S. G. Nieminen by the scientific foundation of the Finnish Association of Agricultural Graduates. We wish to express our sincere gratitude to the Association of Agricultural Graduates and to Director and Mrs. S. G. Nieminen. Mr. Simo Hovinen, M. Sc. from the Plant Breeding Institute of Hankkija was responsible for most of the field experiments. The text was translated into English by Mrs. Liisa-Maija Susiluoto.

\section{References}

BISHOP, L. D. 1928. First report on barley proteins. The composition and quantitive estimation of barley proteins. J. Int. Brew 34: 101-118.

BYERS, M., KIRMAN, M. A. \& MIFLIN, B. J. 1978. Factors affecting the quality and yield of seed protein. (Ed.) NORTON, G. Plant proteins. p. 227-243 London, Boston.

EWART, J. H. D. 1968. Fractional extraction of cereal flour proteins. J. Sci Food and Agric 19: 241-245.

IVANKO, S. 1971. Changeability on protein fractions and their amino acid composition during maturation of barley grain. Biol. Plant. 13: 155-164.

KØIE, B. \& NIELSEN, G. 1977. Extraction and separation of hordeins. 25 p. (Eds) MIFLIN, B. J. \& SHEWRY, P. R. Techniques for separation of barley and maize seed proteins. CEC Eur. 5687e Luxembourg.

MICHAEL, G. 1963. Einfluss der Düngung auf Eiweissqualität und Eiweissfraktionen der Nahrungspflanzen. Qual. Plant. Mat. Veget. 10: 253-265.

- , FAUST, H. \& BLUMER, B. 1960. Die Verteilung von spät gedüngten ${ }^{15} \mathrm{~N}$ in der reifenden Gerstenpflanze unter besonderer Berücksichtigung der Korneiweisse. Z. Pflanzenernährung. Düng. Bodenk. 91: 158-169.

MIFLIN, B. J. \& SHEWRY; P. R. 1979. The biology and biochemistry of cereal seed prolamins. Seed protein improvement in cereals. IAEA-SM-230 Wien, 1979.

MITRA, K. K., BHATIA, C. R. \& RABSON, R. 1979. Bioenergetic cost of altering the amino acid compostition of cereal grains. Cer. Chem. 56: 249-252.

SELKE, W. 1940. Die Wirkung zusätzlicher später Stickstoffgaben auf Ertrag und Qualität der Ernteprodukte. Z. Bodenk. u. Pflanzenernährg 20: 1-49.

ZOSCHKE, M. 1973. Stickstoffernährung und Eiweissbildung bei Futtergersten (Hordeum vulgare L.). Vortschr. Acker- u. Pflanzenb. 2, 59 p.

Ms received May 28, 1982 
Typen lähteen vaikutus ohran valkuaisfraktioiden määriin ja keskinäisiin suhteisiin.

Ulla Lallukka, Eero Varis ja Ritva Repo

Helsingin yliopiston kasvinviljelytieteen laitos

Typen lähteen ja annostelun vaikutusta ohran valkuaisaineiden määriin tutkittiin fraktioimalla jyvän valkuainen sen eri osiin. Aineisto tutkimukseen saatiin Helsingin yliopiston kasvinviljelytieteen laitoksella käynnissä olevasta Suomen Akatemian rahoittamasta biologisen typensidonnan projektista. Aineisto käsitti kolme koesarjaa erilaisten esikasvien sekä viljan ja palkokasvien seosviljelyn typpilannoituksesta.

Fraktiointi suoritettiin menetelmin, joita ei ole aikaisemmin Suomessa käytetty eikä laitteisto täysin vastannut työn tarkkuudelle asetettavia vaatimuksia. Lisäksi aineisto oli suhteellisen pieni, yleensä vain yksi tai kaksi koetta kustakin koemallista. Kun tulokset kuitenkin monelta osin olivat yhdenmukaisia muualla tehtyjen vastaavanlaisten tutkimusten kanssa, voitaneen niiden antamaa kuvaa pitää ainakin tyydyttävän luotettavana.

Typpilannoitus ja typpeä biologisesti sitovat esikasvit lisäsivät ohran jyvän valkuaista ja sen kaikkia eri komponentteja. Vähän lysiiniä sisältävä prolamiini lisääntyi myös suhteellisesti, sen sijaan jyvän alkiossa ja kuorikerroksessa sijaitsevien aineenvaihdunnallisten valkuaisten (I fraktio) suhteellinen osuus väheni valkuaispitoisuuden lisääntyessä.

Typpeä sitovien herneen ja härkäpavun viljely esikasveina muutti valkuaisen koostumusta enemmän prolamiinityppeä sisältäväksi kuin ohralle tai sen esikasville annettu typpilannoitus.

Ohran valkuaispitoisuus nousi selvästi myös silloin, kun ohraa viljeltiin seoksena härkäpavun kanssa. Valkuaisen laadun muutokset olivat tässä tapauksessa yhdenmukaiset väkilannoitetypen vaikutusten kanssa.

Verrattaessa tuloksia useihin ulkomaisiin, todettiin, että suomalainen ohra sisälsi keskimäärin runsaammin metabolisten valkuaisfraktioiden typpeä ja vähemmän varastovalkuaisten sisältämää typpeä. 